\author{
Zh.A. Balkizov ${ }^{1}$, Z.Kh. Guchaeva², A.Kh. Kodzokov³ \\ ${ }^{1}$ Institute of Applied Mathematics and Automation - a branch of the Federal State Budget Scientific \\ Institution of Kabardino-Balkarian Scientific Center of the Russian Academy of Sciences Russia, Nalchik; \\ ${ }^{2,3}$ Kabardino-Balkarian State University named after H.M. Berbekov's, Russia, Nalchik \\ (E-mail: ${ }^{1}$ Giraslan@yandex.ru, ${ }^{2}$ Proporwiz@yandex.ru, ${ }^{3}$ Kodzoko@mail.ru)
}

\title{
The first with displacement problem for a third-order parabolic-hyperbolic equation and the effect of inequality of characteristics as data carriers of the Tricomi problem
}

\begin{abstract}
As part of this scientific work, we study a displacement boundary value problem for a third-order parabolichyperbolic type equation with a third-order parabolic equation backward in time and a wave equation in the domain of hyperbolicity. As one of the boundary conditions we have a linear combination including variable coefficients of the sought function on the characteristic lines $A C$ and $B C$. The present paper reports following results: inequality between characteristics of $A C$ and $B C$ lines limiting the hyperbolic part $\Omega_{1}$ of the domain $\Omega$ as carriers of data for the Tricomi problem as $0 \leq x \leq 2 \pi$, as a matter of fact, the solvability of the Tricomi problem with data on the characteristic line $B C$ does not imply the solvability of the Tricomi problem with data on the $A C$; necessary and sufficient conditions for the existence and uniqueness of a regular solution to the problem under study are found. Under certain conditions for the given functions, the solution to the problem under study is written out explicitly. It is shown that under violation of the necessary conditions established in this paper the homogeneous problem has innumerable linearly independent solutions, while the set of solutions to the corresponding inhomogeneous problem can exist only with additional conditions.
\end{abstract}

Keywords: mixed type equation, third-order parabolic-hyperbolic equation, Tricomi problem, Tricomi method, first with displacement problem, Green's function, Fredholm's integral equation of the second kind.

\section{Problem Statement. Results Summary}

In a Euclidean plane with independent variables $x$ and $y$ consider the equation

$$
0= \begin{cases}u_{x x}-u_{y y}-f_{1}, & y<0 \\ u_{x x x}+u_{y}-f_{2}, & y>0\end{cases}
$$

where $f_{1}=f_{1}(x, y), f_{2}=f_{2}(x, y)$ - are specified functions, $u=u(x, y)$ - is a sought function.

Equation (1) as $y<0$ coincides with the inhomogeneous wave equation

$$
u_{x x}-u_{y y}=f_{1}(x, y),
$$

while as $y>0$ it coincides with the backward in time nonhomogeneous equation

$$
u_{x x x}+u_{y}=f_{2}(x, y),
$$

of the third order with multiple characteristics $[1 ; 9]$ of the parabolic type [2;72].

Equation (1) is considered in the domain $\Omega$, bounded by characteristic lines $A C: x+y=0$ and $C B: \quad x-y=2 \pi$ of equation (2) as $y<0$ starting at the point $C=(\pi,-\pi)$ and passing through the points $A=(0,0)$ and $B=(2 \pi, 0)$ respectively, and by a rectangle with vertices at $A, B, A_{0}=(0, h)$, $B_{0}=(2 \pi, h), h>0$, as $y>0$. Denote $\Omega_{1}=\Omega \cap\{y<0\}, \Omega_{2}=\Omega \cap\{y>0\}, J=\{(x, 0): 0<x<r\}$, $\Omega=\Omega_{1} \cup \Omega_{2} \cup J$.

Assume that a regular solution to equation (1) in the domain $\Omega$ is the function $u=u(x, y)$ of the class $C(\bar{\Omega}) \cap C^{1}(\Omega) \cap C^{2}\left(\Omega_{1}\right) \cap C_{x}^{3}\left(\Omega_{2}\right), u_{x}, \quad u_{y} \in L_{1}(J)$ satisfying equation (1). 
Problem 1. Find a regular solution to equation (1) in the domain $\Omega$ satisfying the conditions

$$
\begin{gathered}
u(0, y)=\varphi_{1}(y), u(2 \pi, y)=\varphi_{2}(y), u_{x}(2 \pi, y)=\varphi_{3}(y), \quad 0 \leq y<h, \\
\alpha(x) u\left[\theta_{0}(x)\right]+\beta(x) u\left[\theta_{\pi}(x)\right]=\psi(x), \quad 0 \leq x \leq 2 \pi,
\end{gathered}
$$

where $\theta_{0}(x)=\left(\frac{x}{2} ;-\frac{x}{2}\right), \theta_{\pi}(x)=\left(\frac{x}{2}+\pi ; \frac{x}{2}-\pi\right)$ - are the points for intersection of the characteristic lines of equation (2), starting at $(x, 0)$ with characteristics of $A C$ and $B C$ respectively; $\varphi_{1}(y), \varphi_{2}(y), \varphi_{3}(y) ; \alpha(x), \beta(x), \psi(x)$ - are the specified functions and what is more $\alpha^{2}(x)+\beta^{2}(x) \neq 0 \quad \forall x \in[0,2 \pi]$.

Formulated problem (1), (4), (5) belongs to the class of A.M. Nakhushev nonlocal boundary value problems with displacement [3].

For the first time, a problem with a boundary condition relating the values of the desired function on two characteristic lines from different families in the hyperbolic part of the domain for the LavrentievBitsadze equation was formulated and studied in [4].

The concept for a boundary value problem with displacement was introduced in [5], [6], and a number of nonlocal boundary value problems with various types of displacements were studied for hyperbolic, degenerate hyperbolic, and mixed type equations. In particular, the posing of the first Darboux problem for wave equation (2) with an initial condition

$$
u(x, 0)=\tau(x), \quad 0 \leq x \leq 1
$$

and non-local condition (5) was generalized in [5]. It was shown that the conditions: $\alpha^{2}(1)+\beta^{2}(0) \neq 0$, $\left.\alpha(x) \neq \beta(x) \forall x \in[0,1], \alpha(x), \beta(x), \tau(x), \psi(x) \in C[0,1] \cap C^{2}\right] 0,1[$ for the given functions $\alpha(x)$, $\beta(x), \tau(x), \psi(x)$ ensures the correctness of the investigated problem with displacement.

In [6], a method of posing of the nonlocal displacement boundary value problems for a degenerate hyperbolic equation of the form

$$
(-y)^{m} u_{x x}-u_{y y}=0, \quad m=\text { const }>0
$$

with the Riemann-Liouville fractional operator. Criteria were found for the unique solvability of the problem with conditions (6) and

$$
\alpha(x) D_{0 x}^{1-\varepsilon} u\left[\theta_{0}(x)\right]+\beta(x) D_{x r}^{1-\varepsilon} u\left[\theta_{r}(x)\right]=\psi(x), \quad 0<x<r
$$

for equation (7), where $\theta_{0}(x), \theta_{r}(x)$ were defined as the intersection points of the characteristic lines of equation (7), as above, and what is more $2(m+2) \varepsilon=m$.

In [7], the first and second Darboux problems were studied for the class of degenerate hyperbolic equations. Sufficient conditions for the given functions providing solvability to the problems were established. It was also shown that the Darboux problem with the following data:

$$
u_{y}(x, 0)=\nu(x),\left.u(x, y)\right|_{A C}=\psi(x), \quad 0<x<r
$$

is well posed for the equation

$$
y^{2} u_{x x}-u_{y y}+u_{x}=0
$$

considered in the domain $D$, bounded by the characteristic lines

$$
A C: 2 x-y^{2}=0, \quad B C: 2 x+y^{2}=2 r, \quad 0 \leq x \leq r
$$

and the segment $I \equiv A B$ of the straight line $y=0$.

$$
u_{y}(x, 0)=\nu(x),\left.\quad u(x, y)\right|_{A C}=\psi(x), \quad 0<x<r .
$$


At the same time, the homogeneous Darboux problem for equation (8) with

$$
u_{y}(x, 0)=0,\left.\quad u(x, y)\right|_{B C}=0, \quad 0<x<r
$$

has nonzero solutions of the form $u(x, y)=g\left(x+\frac{1}{2} y^{2}\right)-g(r)$, where $g=g(x)$ is an arbitrary function of the class $\left.g(x) \in C^{1}\left[\frac{r}{2}, r\right] \cap C^{2}\right] \frac{r}{2}, r$, which indicates the inequality between characteristic lines $A C$ and $B C$ as data carriers of the second Darboux problem for the equation (8) .

The displacement boundary value problems have found their important application in mathematical modeling of biological processes, and transonic gas dynamics. Similar nonlocal boundary conditions arise in the study of heat and mass transfer in capillary-porous bodies, in the mathematical modeling of gas dynamics and nonlocal physical processes, in the study of cell propagation processes, in the theory of electromagnetic field propagation into inhomogeneous medium $[2,8,9]$. Comprehensive bibliographies of scientific literature devoted to the study of boundary value problems with displacements is presented in [3], [10-18], as well as in thesis [19-23].

The displacement boundary value problem with condition (5) for a second-order parabolic-hyperbolic type equation with a heat equation in the parabolic domain was studied in [24]; also a necessary and sufficient condition for the existence of a unique regular solution to the problem under study was found.

In this paper, we study a displacement boundary value problem for a third-order parabolichyperbolic type equation (1) with a third-order parabolic equation backward in time and a wave equation in the domain of hyperbolicity. As one of the boundary conditions we have a linear combination including variable coefficients of the sought function on the characteristic lines $A C$ and $B C$. The present paper reports following results: inequality between characteristics of $A C$ and $B C$ lines limiting the hyperbolic part $\Omega_{1}$ of the domain $\Omega$ as carriers of data for the Tricomi problem as $0 \leq x \leq 2 \pi$. As a matter of fact, the solvability of the Tricomi problem with data on the characteristic line $B C$ does not imply the solvability of the Tricomi problem with data on the $A C$. Necessary and sufficient conditions for the existence and uniqueness of a regular solution to the problem under study are found. Under certain conditions for the given functions, the solution to the problem under study is written out explicitly. It is shown that under violation of the necessary conditions established in this paper the homogeneous problem has innumerable linearly independent solutions, while the set of solutions to the corresponding inhomogeneous problem can exist only with additional conditions. Among the works closely related to our research there are [25-31].

$$
\text { Problem } 1 \text { as } \alpha(x) \equiv 0
$$

The study of problem 1 we begin as $\alpha(x) \equiv 0, \beta(x) \neq 0 \forall x \in[0,2 \pi]$. The following theorem is true.

Theorem 1. Assume that for the given functions $\alpha(x), \beta(x), \psi(x), \varphi_{i}(y), i=\overline{1,3}, f_{1}(x, y)$ and $f_{2}(x, y)$

$$
\begin{gathered}
\alpha(x) \equiv 0, \beta(x) \neq 0 \quad \forall x \in[0,2 \pi], \\
\beta(x), \psi(x) \in C^{1}[0,2 \pi], \\
\varphi_{1}(y), \varphi_{2}(y), \varphi_{3}(y) \in C[0, h], \\
f_{1}(x, y) \in C\left(\bar{\Omega}_{1}\right), f_{2}(x, y) \in C\left(\bar{\Omega}_{2}\right) .
\end{gathered}
$$

be satisfied.

Therefore there exists a unique solution to problem 1.

Indeed, let there exist a solution to problem (1), (4), (5) and let

$$
u(x, 0)=\tau(x), \quad 0 \leq x \leq 2 \pi ; \quad u_{y}(x, 0)=\nu(x), \quad 0<x<2 \pi .
$$


Passing to the limit as $y \rightarrow+0$ in the equation (1), accepting notation (13), we obtain the first basic relation between $\tau(x)$ and $\nu(x)$, transferred from the parabolic domain $\Omega_{2}$ to the line $y=0$ :

$$
\tau^{\prime \prime \prime}(x)+\nu(x)=f_{2}(x, 0), \quad 0<x<2 \pi .
$$

Employing boundary conditions (4) as $y \rightarrow+0$ we can get

$$
\tau(0)=\varphi_{1}(0), \tau(2 \pi)=\varphi_{2}(0), \tau^{\prime}(2 \pi)=\varphi_{3}(0) .
$$

Next we can find basic relation between $\tau(x)$ and $\nu(x)$, transferred from the hyperbolic part $\Omega_{1}$ of the domain $\Omega$ to the line of the type changing $y=0$. Let condition (9) of Theorem 1 be satisfied. In this case, the studied problem (1), (4), (5) becomes one of the analogues of the Tricomi problem for equation (1) with (4) and

$$
\left.u(x, y)\right|_{B C}=u\left[\theta_{\pi}(x)\right]=\frac{\psi(x)}{\beta(x)}, \quad 0 \leq x \leq 2 \pi .
$$

To find the relationship between $\tau(x)$ and $\nu(x)$ let us use representation of the solution to problem (13) for equation $(2)[32 ; 59]$ :

$$
u(x, y)=\frac{\tau(x+y)+\tau(x-y)}{2}+\frac{1}{2} \int_{x-y}^{x+y} \nu(t) d t-\frac{1}{2} \int_{0}^{y} \int_{x-y+s}^{x+y-s} f_{1}(t, s) d t d s .
$$

By formulae (17) we can find:

$$
u\left[\theta_{\pi}(x)\right]=u\left(\frac{x+2 \pi}{2}, \frac{x-2 \pi}{2}\right)=\frac{\tau(2 \pi)+\tau(x)}{2}-\frac{1}{2} \int_{x}^{2 \pi} \nu(t) d t+\frac{1}{2} \int_{\frac{x}{2}-\pi}^{0} \int_{2 \pi+s}^{x-s} f_{1}(t, s) d t d s .
$$

Substituting value $u\left[\theta_{\pi}(x)\right]$ from (18) into (16) we can get

$$
\tau(2 \pi)+\tau(x)-\int_{x}^{2 \pi} \nu(t) d t+\int_{\frac{x}{2}-\pi}^{0} \int_{2 \pi+s}^{x-s} f_{1}(t, s) d t d s=\frac{2 \psi(x)}{\beta(x)}
$$

hence

$$
\nu(x)=-\tau^{\prime}(x)+\left(\frac{2 \psi(x)}{\beta(x)}\right)^{\prime}-\int_{\frac{x}{2}-\pi}^{0} f_{1}(x-s, s) d s .
$$

Relation (19) is the basic relation between the sought functions $\tau(x)$ and $\nu(x)$ transferred from the hyperbolic part $\Omega_{1}$ of the domain $\Omega$ to the line $y=0$ of the type changing of equation (1) as $\alpha(x) \equiv 0, \beta(x) \neq 0 \quad \forall x \in[0,2 \pi]$.

By relations (14) and (19) for the sought function $\tau=\tau(x)$ we arrive at the finding a solution to the equation

$$
\tau^{\prime \prime \prime}(x)-\tau^{\prime}(x)=f_{2}(x, 0)+\int_{\frac{x}{2}-\pi}^{0} f_{1}(x-s, s) d s-\left(\frac{2 \psi(x)}{\beta(x)}\right)^{\prime}, \quad 0<x<2 \pi,
$$


satisfying conditions (15). A solution to problem (20), (15), under conditions (9)-(12) for given functions exists, is unique, and can be written out by the formula:

$$
\begin{gathered}
\tau(x)=\frac{1}{4 \pi^{2}}\left[(2 \pi-x)^{2}+2 \int_{0}^{2 \pi} G(x, t)(t-2 \pi) d t\right] \varphi_{1}(0)+ \\
+\frac{1}{4 \pi^{2}}\left[x(4 \pi-x)-2 \int_{0}^{2 \pi} G(x, t)(t-2 \pi) d t\right] \varphi_{2}(0)+ \\
+\frac{1}{2 \pi}\left[x(x-2 \pi)+2 \int_{0}^{2 \pi} G(x, t)(t-\pi) d t\right] \varphi_{3}(0)+\int_{0}^{2 \pi} G(x, t) f_{2}(t, 0) d t+ \\
+\int_{0}^{2 \pi} G(x, t) \int_{\frac{t}{2}-\pi}^{2 \pi} f_{1}(t-s, s) d s d t-2 \int_{0}^{2 \pi} G(x, t)\left(\frac{\psi(t)}{\beta(t)}\right)^{\prime} d t
\end{gathered}
$$

where $G(x, t)=-\frac{1}{1-\operatorname{ch}(2 \pi)} \begin{cases}(1-\operatorname{ch} t)(1-\operatorname{ch}(2 \pi-x))-(1-\operatorname{ch}(x-t))(1-\operatorname{ch}(2 \pi)), & 0 \leq x<t, \\ (1-\operatorname{cht})(1-\operatorname{ch}(2 \pi-x)), & t<x \leq 2 \pi .\end{cases}$

\section{Problem 1 as $\beta(x) \equiv 0$}

Assume that further specified functions $\alpha(x)$ and $\beta(x)$ are such that

$$
\beta(x) \equiv 0, \alpha(x) \neq 0 \quad \forall x \in[0,2 \pi] .
$$

The following theorem is true.

Theorem 2. Let condition (21) be satisfied for the given functions $\alpha(x)$ and $\beta(x)$, and $\alpha(x) \in C^{1}[0,2 \pi]$. This implies that the homogeneous problem corresponding to the problem under study 1 has innumerable linearly independent solutions, while the inhomogeneous problem (1), (4), (5) is solvable if and only if the additional condition is satisfied.

Indeed let condition (21) be satisfied for $\alpha(x)$ and $\beta(x)$. Then problem 1 becomes the Tricomi problem for equation (1) with conditions (4) and

$$
\left.u(x, y)\right|_{A C}=u\left[\theta_{0}(x)\right]=\frac{\psi(x)}{\alpha(x)}, \quad 0 \leq x \leq 2 \pi .
$$

By (17) with condition (22) we can find:

$$
u\left[\theta_{0}(x)\right]=u\left(\frac{x}{2},-\frac{x}{2}\right)=\frac{\tau(0)+\tau(x)}{2}+\frac{1}{2} \int_{x}^{0} \nu(t) d t-\frac{1}{2} \int_{0}^{-x / 2} \int_{x+s}^{-s} f_{1}(t, s) d t d s .
$$

Substituting value $u\left[\theta_{0}(x)\right]$ from (23) into condition (22) using differentiation, we arrive at a fundamental relation

$$
\nu(x)=\tau^{\prime}(x)-\int_{-x / 2}^{0} f_{1}(x+s, s) d s-2\left(\frac{\psi(x)}{\alpha(x)}\right)^{\prime} .
$$

Taking out the function $\nu(x)$ from (14) and (24) we can find a solution to the equation 


$$
\tau^{\prime \prime \prime}(x)+\tau^{\prime}(x)=F(x)
$$

satisfying conditions (15), where $F(x)=f_{2}(x, 0)+\int_{-x / 2}^{0} f_{1}(x+s, s) d s+2\left(\frac{\psi(x)}{\alpha(x)}\right)^{\prime}$.

Problem (25), (15) corresponds to the homogeneous problem

$$
\begin{gathered}
\tau^{\prime \prime \prime}(x)+\tau^{\prime}(x)=0 \\
\tau(0)=0, \tau(2 \pi)=0, \tau^{\prime}(2 \pi)=0 .
\end{gathered}
$$

The homogeneous problem (26), (27) corresponding to problem (25), (15) has the nonzero solution

$$
\tau(x)=c(1-\cos x), \quad c=\text { const. }
$$

The solution to the inhomogeneous problem (25), (15) in this case exists only under the additional condition for the given functions

$$
\varphi_{2}(0)-\varphi_{1}(0)=\int_{0}^{2 \pi}(1-\cos t) F(t) d t .
$$

If condition (28) is satisfied, then the set of solutions to problem (25), (15) is written out by the formula:

$$
\tau(x)=\int_{0}^{x}[1-\cos x \cos t] F(t) d t+\int_{x}^{2 \pi} \sin x \sin t F(t) d t+\varphi_{1}(0) \cos x+\varphi_{3}(0)+c(1-\cos x) .
$$

It follows from the above that the characteristic lines $A C$ and $B C$ limiting the hyperbolic part $\Omega_{1}$ of the domain $\Omega$ are not equal as carriers of data for the Tricomi problem as $0 \leq x \leq 2 \pi$. And generally speaking, the solvability of the Tricomi problem with data on the characteristic line BC does not imply the solvability of the Tricomi problem with data on AC.

\section{Mean value theorem}

Now find in general the basic relationship between $\tau(x)$ and $\nu(x)$ transferred from the hyperbolic part $\Omega_{1}$ of the domain $\Omega$ on the line of type changing $y=0$. For this purpose, prove the following lemma (theorem) on the mean value for an inhomogeneous one-dimensional wave equation (2).

Lemma 1. Any regular solution to equation (2) satisfying the condition $u(x, 0)=\tau(x)$ possesses the following property

$$
\begin{aligned}
u\left[\theta_{0}(x)\right]+u\left[\theta_{\pi}(x)\right]=u(x, 0)+u(\pi,-\pi)+\frac{1}{2} \int_{-\pi}^{0} \int_{-s}^{2 \pi+s} f_{1}(t, s) d t d s- \\
\quad-\frac{1}{2} \int_{\frac{x}{2}-\pi}^{0} \int_{x-s}^{2 \pi+s} f_{1}(t, s) d t d s-\frac{1}{2} \int_{-x / 2}^{0} \int_{-s}^{x+s} f_{1}(t, s) d t d s .
\end{aligned}
$$

Indeed, taking into account formulas (18) and (23), we find

$$
u\left[\theta_{0}(x)\right]+u\left[\theta_{\pi}(x)\right]=\tau(x)+\frac{\tau(0)+\tau(2 \pi)}{2}-\frac{1}{2} \int_{0}^{2 \pi} \nu(t) d t-
$$




$$
-\frac{1}{2} \int_{0}^{\frac{x}{2}-\pi} \int_{2 \pi+s}^{x-s} f_{1}(t, s) d t d s-\frac{1}{2} \int_{0}^{-x / 2} \int_{x+s}^{-s} f_{1}(t, s) d t d s .
$$

By $(17)$ as $(x, y)=(\pi,-\pi)$ it is easy to show that

$$
\frac{\tau(0)+\tau(2 \pi)}{2}-\frac{1}{2} \int_{0}^{2 \pi} \nu(t) d t=u(\pi,-\pi)+\frac{1}{2} \int_{0}^{-\pi} \int_{2 \pi+s}^{-s} f(t, s) d t d s .
$$

By (30) and (31) we arrive at (29).

Now we employ formula (29) to take forward steps. Find the value of $u(\pi ;-\pi)$. Using boundary condition (5) as $\mathrm{x}=0$ and in view of the first condition of (15), we find

$$
\alpha(0) \varphi_{1}(0)+\beta(0) u(\pi ;-\pi)=\psi(0)
$$

whence as $\beta(0) \neq 0$ find

$$
u(\pi ;-\pi)=\frac{\psi(0)-\alpha(0) \varphi_{1}(0)}{\beta(0)} .
$$

Similarly as $x=2 \pi$ and $\alpha(2 \pi) \neq 0$ by (5) and (15) find

$$
u(\pi ;-\pi)=\frac{\psi(2 \pi)-\beta(2 \pi) \varphi_{2}(0)}{\alpha(2 \pi)} .
$$

Thus, if $\alpha^{2}(2 \pi)+\beta^{2}(0) \neq 0$, the value of the sought function $u(x, y)$ at the point $C=(\pi ;-\pi)$ is found by formulas (32) or (33). Assume, for example, that $\alpha(2 \pi) \neq 0$. Therefore, equality (29) can be rewritten as follows

$$
u\left[\theta_{0}(x)\right]+u\left[\theta_{\pi}(x)\right]=\tau(x)+F_{1}(x),
$$

where $F_{1}(x)=\frac{\psi(2 \pi)-\beta(2 \pi) \varphi_{2}(0)}{\alpha(2 \pi)}+\frac{1}{2}\left(\int_{-\pi}^{0} \int_{-s}^{2 \pi+s}-\int_{\frac{x}{2}-\pi}^{0} \int_{x-s}^{2 \pi+s}-\int_{-x / 2}^{0} \int_{-s}^{x+s}\right) f_{1}(t, s) d t d s$.

$$
\text { Problem } 1 \text { as } \alpha(x) \equiv \beta(x)
$$

Next consider the case as $\alpha(x) \equiv \beta(x) \forall x \in[0, r]$. The following theorem is true.

Theorem 3. Let the given functions $\varphi_{1}(y), \varphi_{2}(y), \varphi_{3}(y) ; \alpha(x), \beta(x), \psi(x) ; f_{1}(x, y), f_{2}(x, y)$ be such that:

$$
\begin{gathered}
\alpha(x) \equiv \beta(x) \neq 0, \quad \forall x \in[0,2 \pi], \\
\alpha^{2}(0)+\alpha^{2}(2 \pi) \neq 0 ; \\
\left.\varphi_{1}(y), \varphi_{2}(y), \varphi_{3}(y) \in C[0, h] \cap C^{1}\right] 0, h[; \\
\left.\alpha(x), \psi(x) \in C^{1}[0,2 \pi] \cap C^{3}\right] 0,2 \pi[; \\
f_{1}(x, y) \in C^{1}\left(\bar{\Omega}_{1}\right), f_{2}(x, y) \in C\left(\bar{\Omega}_{2}\right) .
\end{gathered}
$$

Then there exists a unique solution to Problem 1 that is regular in the domain $\Omega$.

Indeed, by (5) in view of (34) and (35) find

$$
\tau(x)=\frac{\psi(x)}{\alpha(x)}-F_{1}(x) .
$$


Whence under conditions (38), (39) by (14) we have

$$
\nu(x)=f_{2}(x, 0)-\tau^{\prime \prime \prime}(x)=f_{2}(x, 0)-\left(\frac{\psi(x)}{\alpha(x)}-F_{1}(x)\right)^{\prime \prime \prime} .
$$

With values found for $\tau(x)$ and $\nu(x)$ the solution to the initial problem (1), (4), (5) in the domain $\Omega_{1}$ is written out by formula (17). While the solution to the boundary value problem in the domain $\Omega_{2}$ for equation (3) with boundary conditions (4) and initial condition $u(x, 0)=\tau(x)$ is written out as below:

$$
\begin{gathered}
u(x, y)=\frac{1}{\pi}\left\{\int_{0}^{y} G(x,-y ; 0,-\eta) \varphi_{3}(\eta) d \eta-\int_{0}^{y} G_{\xi \xi}(x,-y ; 0,-\eta) \varphi_{1}(\eta) d \eta+\right. \\
\left.+\int_{0}^{y} G_{\xi \xi}(x,-y ; r,-\eta) \varphi_{2}(\eta) d \eta+\int_{0}^{2 \pi} G(x,-y ; \xi, 0) \tau(\xi) d \xi+\int_{0}^{y} \int_{0}^{r} G(x,-y ; \xi,-\eta) f(\xi, \eta) d \xi d \eta\right\},
\end{gathered}
$$

where $G(x, y ; \xi, \eta)=U(x, y ; \xi, \eta)-W(x, y ; \xi, \eta)$ - Green's function of the operator, $U(x, y ; \xi, \eta)$ and $W(x, y ; \xi, \eta)$ are fundamental solutions to equation $(2)[1 ; 135]$.

Thus, in contrast to the problem with conditions (5) and for a strictly hyperbolic equation (2) [6] the problem with displacement (4) - (5) for equation (1) is uniquely solvable even as $\alpha(x) \equiv \beta(x) \neq 0$ $\forall x \in[0,2 \pi]$ with the functions $\varphi_{1}(y), \varphi_{2}(y), \varphi_{3}(y) ; \alpha(x), \beta(x), \psi(x) ; f_{1}(x, y), f_{2}(x, y)$ possessing properties (36)-(39).

\section{Problem 1, general case}

Further assume that $\alpha(x) \neq \beta(x) \forall x \in[0,2 \pi]$. The following uniqueness theorem holds for a regular solution to the problem (1), (4), (5).

Theorem 4. Let the following conditions:

$$
\begin{gathered}
\alpha(x), \beta(x) \in C^{1}[0,2 \pi] \\
\alpha^{2}(x)+\beta^{2}(x) \neq 0 \quad \forall x \in[0,2 \pi], \\
\alpha^{2}(2 \pi)+\beta^{2}(0) \neq 0, \\
\alpha(x) \neq \beta(x) \quad \forall x \in[0,2 \pi] \\
{\left[\frac{\alpha(x)+\beta(x)}{\alpha(x)-\beta(x)}\right]^{\prime}>0 \quad \forall x \in[0,2 \pi] .}
\end{gathered}
$$

be satisfied for the given functions $\alpha(x)$ and $\beta(x)$.

Then the solution to problem 1 is unique within the required class.

Proof. Under condition (44) of (5) and (34) arrive at the following system of linear algebraic equations

$$
\left\{\begin{array}{l}
u\left[\theta_{0}(x)\right]+u\left[\theta_{\pi}(x)\right]=\tau(x)+F_{1}(x) \\
\alpha(x) u\left[\theta_{0}(x)\right]+\beta(x) u\left[\theta_{\pi}(x)\right]=\psi(x)
\end{array}\right.
$$

for the unknown $u\left[\theta_{0}(x)\right]$ and $u\left[\theta_{\pi}(x)\right]$. When solving (46) we find that

$$
u\left[\theta_{0}(x)\right]=\frac{\beta(x)}{\beta(x)-\alpha(x)} \tau(x)+\frac{\beta(x) F_{1}(x)-\psi(x)}{\beta(x)-\alpha(x)} .
$$

On the other hand, by formula (17) 


$$
u\left[\theta_{0}(x)\right]=\frac{\varphi_{1}(0)+\tau(x)}{2}-\frac{1}{2} \int_{0}^{x} \nu(s) d s+\frac{1}{2} \int_{-x / 2}^{0} \int_{-t}^{x+t} f_{1}(s, t) d s d t .
$$

Substituting the value of $u\left[\theta_{0}(x)\right]$ (48) into (47), and differentiating the resulting equality, we arrive at

$$
\nu(x)=[a(x) \tau(x)]^{\prime}-F_{2}(x),
$$

where $a(x)=\frac{\alpha(x)+\beta(x)}{\alpha(x)-\beta(x)}, F_{2}(x)=\int_{-x / 2}^{0} f_{1}(x+t, t) d t+2\left[\frac{\beta(x) F_{1}(x)-\psi(x)}{\alpha(x)-\beta(x)}\right]^{\prime}$.

Relation (49) is the basic relation between $\tau(x)$ and $\nu(x)$ when conditions (41)-(44) are met.

For the homogeneous problem $\left(\varphi_{i}(y)=f_{j}(x, y)=\psi(x) \equiv 0, i=\overline{1,3}, j=\overline{1,2}\right)$ corresponding to the initial problem (1), (4), (5) consider the integral

$$
J=\int_{0}^{2 \pi} \tau(x) \nu(x) d x
$$

In view of relation (14) under conditions (15) we have that the integral in question

$$
J=\int_{0}^{2 \pi} \tau(x) \nu(x) d x=-\int_{0}^{2 \pi} \tau(x) \tau^{\prime \prime \prime}(x) d x=-\frac{1}{2}\left[\tau^{\prime}(0)\right]^{2} \leq 0 .
$$

And in view of relation (49) we have

$$
J=\int_{0}^{r} \tau(x) \nu(x) d x=\int_{0}^{r} \tau(x)[a(x) \tau(x)]^{\prime} d x=\frac{1}{2} \int_{0}^{r} a^{\prime}(x) \tau^{2}(x) d x .
$$

Provided that conditions (41)-(45) of Theorem 2 are satisfied, by inequalities (50) and (51) we have that $\tau(x) \equiv 0$. Moreover, by relations (14) or (49) we have that $\nu(x) \equiv 0$. Then by formula (17) we can conclude $u(x, y) \equiv 0$ in $\Omega_{1}$, while by $(40) u(x, y) \equiv 0$ in $\Omega_{2}$. Thus, it is shown that the homogeneous problem corresponding to (1), (4), (5) under the conditions of Theorem 2 has only a trivial solution $u(x, y) \equiv 0$ in $\Omega$ that implies the uniqueness of a regular solution to the investigated problem 1.

Theorem 5. Let the conditions (11), (12), (41), (42), (43), (44), (45) be satisfied for the given functions $\varphi_{1}(y), \varphi_{2}(y), \varphi_{3}(y) ; \alpha(x), \beta(x), \psi(x) ; f_{1}(x, y), f_{2}(x, y)$ and let:

$$
\psi(x) \in C^{1}[0,2 \pi]
$$

Then there is a regular solution to Problem 1.

Proof. To prove Theorem 5 return again to relations (14), (15) and (49). Take out from (14) and (49) the sought function $\nu(x)$, and find for $\tau(x)$ a solution to the ordinary second-order differential equation of the form

$$
\tau^{\prime \prime \prime}(x)+a(x) \tau^{\prime}(x)+a^{\prime}(x) \tau(x)=f_{2}(x, 0)+F_{2}(x), \quad 0<x<2 \pi,
$$

satisfying conditions (15). 
By integrating equation (53) three times from $x$ до tо $2 \pi$ we arrive at the integral equation

$$
\tau(x)-\frac{1}{4 \pi^{2}} \int_{0}^{2 \pi} K(x, t) a(t) \tau(t) d t=F_{3}(x),
$$

where $K(x, t)= \begin{cases}(2 \pi-x)^{2} t-4 \pi^{2}(t-x), & 0 \leq x<t \\ (2 \pi-x)^{2} t, & t<x \leq 2 \pi\end{cases}$

$$
\begin{gathered}
F_{3}(x)=\left(1-\frac{x}{2 \pi}\right)^{2} \varphi_{1}(0)+\frac{x(4 \pi x-x)}{4 \pi^{2}} \varphi_{2}(0)+\frac{x(x-2 \pi)}{2 \pi} \varphi_{3}(0)+ \\
+\frac{(2 \pi-x)^{2}}{8 \pi^{2}} \int_{0}^{2 \pi} t^{2}\left[f_{2}(t, 0)+F_{2}(t)\right] d t-\frac{1}{2} \int_{x}^{2 \pi}(t-x)^{2}\left[f_{2}(t, 0)+F_{2}(t)\right] d t
\end{gathered}
$$

corresponding to problem (53), (15).

Equation (54) is a Fredholm integral equation of the second kind with the kernel $K(x, t) \in$ $\in C([0,2 \pi] \times[0,2 \pi])$ and with the right-hand side $F_{3}(x) \in C^{1}[0,2 \pi]$. The unique solvability of equation (54) under conditions (41) - (45) involving the functions $\alpha(x)$ and $\beta(x)$ follows from the uniqueness theorem proved above. Properties (11), (12) and (52) imply that the solution $\tau=\tau(x)$ to equation (54) belongs to the class $\left.\tau(x) \in C[0,2 \pi] \cap C^{3}\right] 0,2 \pi[$.

$$
\text { Problem } 1 \text { as }\left[\frac{\alpha(x)+\beta(x)}{\alpha(x)-\beta(x)}\right]^{\prime} \equiv 0
$$

Finally, consider the case as $a^{\prime}(x)=\left[\frac{\alpha(x)+\beta(x)}{\alpha(x)-\beta(x)}\right]^{\prime} \equiv 0 \quad \forall x \in[0,2 \pi]$, i.e.

$$
a(x)=\frac{\alpha(x)+\beta(x)}{\alpha(x)-\beta(x)}=a=\text { const } \quad \forall x \in[0,2 \pi] .
$$

Under condition (55) from (53) we can arrive at the following problem for $\tau(x)$

$$
\begin{gathered}
\tau^{\prime \prime \prime}(x)+a \tau^{\prime}(x)=f_{2}(x, 0)+F_{2}(x), \quad 0<x<2 \pi, \\
\tau(0)=\varphi_{1}(0), \tau(2 \pi)=\varphi_{2}(0), \tau^{\prime}(2 \pi)=\varphi_{3}(0) .
\end{gathered}
$$

The solution to problem (56) - (57) is written out by the formula

$$
\begin{gathered}
\tau(x)=\frac{1}{4 \pi^{2}}\left[(2 \pi-x)^{2}+2 a \int_{0}^{2 \pi}(2 \pi-t) G(x, t) d t\right] \varphi_{1}(0)+ \\
+\frac{1}{4 \pi^{2}}\left[1-(2 \pi-x)^{2}-2 a \int_{0}^{2 \pi}(2 \pi-t) G(x, t) d t\right] \varphi_{2}(0)+ \\
+\frac{1}{2 \pi}\left[x^{2}-2 \pi x+2 a \int_{0}^{2 \pi}(\pi-t) G(x, t) d t\right] \varphi_{3}(0)+\int_{0}^{2 \pi} G(x, t)\left[f_{2}(t, 0)+F_{2}(t)\right] d t .
\end{gathered}
$$

The function $G(x, t)$ in (58) is Green's function of the operator $L[\tau(x)]=\tau^{\prime \prime \prime}(x)+a \tau^{\prime}(x)$ with condition (57), whose explicit form is determined depending on the sign of the number $a$ by one of the formulas below: 


$$
\begin{gathered}
G(x, t)=\frac{1}{a[1-\operatorname{ch}(2 \sqrt{-a} \pi)]}\left\{\begin{array}{l}
{[1-\operatorname{ch}(\sqrt{-a}(2 \pi-x))][1-\operatorname{ch}(\sqrt{-a} t)]-} \\
-[1-\operatorname{ch}(2 \sqrt{-a} \pi)][1-\operatorname{ch}(\sqrt{-a}(x-t))], \quad 0 \leq x<t, \quad \text { as } a<0 ; \\
{[1-\operatorname{ch}(\sqrt{-a}(2 \pi-x))][1-\operatorname{ch}(\sqrt{-a} t)], \quad t<x \leq 2 \pi,}
\end{array}\right. \\
G(x, t)=\frac{1}{8 \pi^{2}}\left\{\begin{array}{l}
t^{2}(2 \pi-x)^{2}-4 \pi^{2}(t-x)^{2}, \quad 0 \leq x<t, \quad \text { as } a=0 ; \\
t^{2}(2 \pi-x)^{2}, \quad t<x \leq 2 \pi
\end{array}\right.
\end{gathered}
$$

and

$$
G(x, t)=\frac{1}{a[1-\cos (2 \sqrt{a} \pi)]} \begin{cases}{[1-\cos (\sqrt{a} t)][1-\cos (\sqrt{a}(2 \pi-x))]-} & \\ -[1-\cos (2 \sqrt{a} \pi)][1-\cos (\sqrt{a}(x-t))], & 0 \leq x<t, \\ {[1-\cos (\sqrt{a} t)][1-\cos (\sqrt{a}(2 \pi-x))],} & t<x \leq 2 \pi,\end{cases}
$$

as $a>0$ and $a \neq n^{2}, n \in N$.

In each cases considered above with the value found for the function $\tau(x)$ within the fundamental relations (14) or (49) we can also find a value for the function $\nu(x)$. At that, the solution of the initial problem (1), (4), (5) in the domain $\Omega_{1}$ is written out by the d'Alembert formula (17), while in $\Omega_{2}$ the solution to problem (3), (4) with $u(x, 0)=\tau(x)$ is written out by formula (40).

Provided that $a(x)=\frac{\alpha(x)+\beta(x)}{\alpha(x)-\beta(x)}=a=n^{2} \quad \forall x \in[0,2 \pi], n \in N$ the homogeneous problem corresponding to problem (56), (57) has nonzero solutions $\tau(x)=c(1-\cos n x), c=$ const. The function $G(x, t)$ in this case does not exist, and a solution to problem (56)-(57) can exist with the additional condition

$$
\int_{0}^{2 \pi}\left[F_{2}(t)+f_{2}(t, 0)\right][\cos (n t)-1] d t=n^{2}\left[\varphi_{1}(0)-\varphi_{2}(0)\right]
$$

be satisfied.

As condition (59) is satisfied the solution to problem 1 in the domain $\Omega_{1}$ is written out by the formula

$$
u(x, y)=\frac{g(x+y)+g(x-y)}{2}+\frac{1}{2} \int_{x-y}^{x+y} \nu(t) d t-\frac{1}{2} \int_{0}^{y} \int_{x-y+s}^{x+y-s} f_{1}(t, s) d t d s,
$$

while in the domain $\Omega_{2}$ the solution is written out as below

$$
\begin{gathered}
u(x, y)=\frac{1}{\pi}\left\{\int_{0}^{y} G(x,-y ; 0,-\eta) \varphi_{3}(\eta) d \eta-\int_{0}^{y} G_{\xi \xi}(x,-y ; 0,-\eta) \varphi_{1}(\eta) d \eta+\right. \\
\left.+\int_{0}^{y} G_{\xi \xi}(x,-y ; r,-\eta) \varphi_{2}(\eta) d \eta+\int_{0}^{2 \pi} G(x,-y ; \xi, 0) g(\xi) d \xi+\int_{0}^{y} \int_{0}^{r} G(x,-y ; \xi,-\eta) f(\xi, \eta) d \xi d \eta\right\},
\end{gathered}
$$

where $g(x)$ is an arbitrary, fairly smooth function, and $G(x, y ; \xi, \eta)=U(x, y ; \xi, \eta)-W(x, y ; \xi, \eta)$, as above, is the Green function of the operator $L u=u_{x x x}-u_{y}, U(x, y ; \xi, \eta)$ and $W(x, y ; \xi, \eta)$ are fundamental solutions to equation $(2)$ [1; 135].

\section{References}

1 Джураев Т.Д. Краевые задачи для уравнений смешанного и смешанно-составного типов / Т.Д. Джураев. - Ташкент: ФАН, 1979. - 239 с. 
2 Нахушев А.М. Уравнения математической биологии / А.М. Нахушев. - М.: Высш. шк., 1995. - $301 \mathrm{c}$.

3 Нахушев А.М. Задачи со смещением для уравнений в частных производных / А.М. Нахушев. - М.: Наука, 2006. - 287 с.

4 Жегалов В.И. Краевая задача для уравнения смешанного типа с граничными условиями на обеих характеристиках и с разрывами на линии перехода / В.И. Жегалов // Ученые записки Казан. ун-та. - 1962. - Т. 122. - Кн. 3. - С. 3-16.

5 Нахушев А.М. О некоторых краевых задачах для гиперболических уравнений и уравнений смешанного типа / А.М. Нахушев // Дифференциальные уравнения. - 1969. - Т. 5. - № 1 . - C. 44-59.

6 Нахушев А.М. Новая краевая задача для одного вырождающегося гиперболического уравнения / А.М. Нахушев // Докл. АН СССР. - 1969. - Т. 187. - № 4. - С. 736-739.

7 Нахушев А.М. О задаче Дарбу для вырождающихся гиперболических уравнений / А.М. Нахушев // Дифференциальные уравнения. - 1971. - Т. 7. - № 1. - С. 49-56.

8 Берс Л. Математические вопросы дозвуковой и околозвуковой газовой динамики / Л. Берс. - М.: Иностранная литература, 1961. - 208 с.

9 Франкль Ф.И. Избранные труды по газовой динамике / Ф.И. Франкль. - М.: Наука, 1973. $-712 \mathrm{c}$.

10 Салахитдинов М.С. Уравнения смешанно-составного типа / М.С. Салахитдинов. - Ташкент: Фан, 1974. - 156 с.

11 Репин О.А. Краевые задачи со смещением для уравнений гиперболического и смешанного типа / О.А. Репин. - Самара: Изд-во Самар. филиала Саратов. гос. экон. ун-та, 1992. $161 \mathrm{c.}$

12 Кальменов Т.Ш. Краевые задачи для линейных уравнений в частных производных гиперболического типа / Т.Ш. Кальменов. - Шымкент: Гылая, 1993. - 328 с.

13 Жегалов В.И. Дифференциальные уравнения со старшими частными производными / В.И. Жегалов, А.Н. Миронов. - Казань: Казан. мат. общ-во, 2001. - 226 с.

14 Репин О.А. Краевые задачи для уравнений в частных производных с разрывными коэффициентами / О.А. Репин, А.А. Килбас, О.И. Маричев. - Самара: Изд-во Самар. гос. экон. ун-та, 2008. - 275 с.

15 Пулькина Л.С. Задачи с неклассическими условиями для гиперболических уравнений / Л.С. Пулькина. - Самара: Изд-во Самар. гос. экон. ун-та, 2012. - 194 с.

16 Сабитов К.Б. К теории уравнений смешанного типа / К.Б. Сабитов. - М.: Физматлит, 2014. $-304 \mathrm{c}$.

17 Сабитов К.Б. Прямые и обратные задачи для уравнений параболо-гиперболического типа / К.Б. Сабитов. - Уфа: Гилем, 2015. - 240 с.

18 Нахушева 3.А. Нелокальные краевые задачи для основных и смешанного типов дифференциальных уравнений / З.А. Нахушева. - Нальчик: КБНЦ РАН, 2011. - 196 с.

19 Салахитдинов М.С. К теории уравнений третьего порядка смешанно-составного типа: дис. ... д-ра физ.-мат. наук / М.С. Салахитдинов. - Ташкент, 1967.

20 Нахушев A.M. K теории линейных краевых задач для гиперболических и смешанных уравнений второго порядка: дис. ... д-ра физ.-мат. наук / А.М. Нахушев. - Новосибирск, 1970. $-172 \mathrm{c}$.

21 Жегалов В.И. Исследование краевых задач со смещением для уравнений смешанного типа: дис. ... д-ра физ.-мат. наук / В.И. Жегалов. - Новосибирск, 1988. 
22 Сабитов К.Б. Некоторые вопросы качественной и спектральной теории уравнений смешанного типа: дис. ... д-ра физ.-мат. наук / К.Б. Сабитов. - М., 1991. - 313 с.

23 Репин О.А. Краевые задачи для уравнений гиперболического и смешанного типов и дробное интегро-дифференцирование: дис. ... д-ра физ.-мат. наук / О.А. Репин. - Минск, 1998.

24 Балкизов Ж.А. Об одной краевой задаче типа задачи Трикоми для уравнения смешанного параболо-гиперболического типа второго порядка с тремя смещениями в гиперболической части области / Ж.А. Балкизов // Науч. ведомости Белгород. гос. ун-та. Сер. Математика. Физика. - 2019. - Т. 51. - № 1. - C. 5-14. - DOI 10.18413/2075-4639-2019-51-1-5-14.

25 Репин О.А. Нелокальная краевая задача для параболо-гиперболического уравнения с характеристической линией изменения типа / О.А. Репин // Дифференциальные уравнения. - 1992. - Т. 28. - № 1. - С. 173-176.

26 Килбас А.А. Задача со смещением для параболо-гиперболического уравнения / А.А. Килбас, О.А. Репин // Дифференциальные уравнения. - 1998. - Т. 34. - № 6. - С. 799-805.

27 Репин О.А. Нелокальная краевая задача для параболо-гиперболического уравнения с нехарактеристической линией изменения типа / О.А. Репин, С.В. Ефимова // Вестн. СамГТУ. Сер. физ.-мат. науки. - 2002. - Вып. 16. - С. 10-14.

28 Ефимова С.В. Задача с нелокальными условиями на характеристиках для уравнения влагопереноса / С.В. Ефимова, О.А. Репин // Дифференциальные уравнения. - 2004. - Т. 40. - № 10. - С. 1419-1422.

29 Мирсабуров М. О задаче с тремя вариантами смещений для уравнения смешанного типа / М. Мирсабуров, С.Т. Чориева // Изв. вузов. Сер. Математика. - 2016. - № 4. - С. 32-45.

30 Ефимова С.В. Нелокальная задача для гиперболического уравнения, вырождающегося внутри области / С.В. Ефимова // Вестн. Самар. гос. техн. ун-та. Сер. физ.-мат. науки. -2005. - Вып. 34. - С. 194-196.

31 Балкизов Ж.А. Краевая задача со смещением для модельного уравнения параболо-гиперболического типа третьего порядка / Ж.А. Балкизов // Вестн. КРАУНЦ. Сер. Физ.-мат. науки. - 2018. - № 3(23). - C. 19-26. DOI: 10.18454/2079-6641-2018-23-3-19-26.

32 Тихонов А.Н. Уравнения математической физики / А.Н. Тихонов, А.А. Самарский. - М.: Наука, 1977. - 736 с.

\author{
Ж.А. Балкизов, З.Х. Гучаева, А.Х. Кодзоков
}

\title{
Үшінші ретті парабола-гиперболалық типті теңдеу үшін ығысумен берілген бірінші теңдеу және Трикоми есебінің тасымалдаушысы ретіндегі сипаттаушылардың тең еместігінің әсері
}

\begin{abstract}
Мақалада үшінші ретті парабола-гиперболалық типті гиперболалық облыста уақытқа қарсы және толқындық теңдеулі үшінші ретті параболалық теңдеулі біртекті емес теңдеу үшін бір шекаралық шарт есебінде $A C$ және $B C$ характеристикаларында ізделінді функцияның мәндерінен тәуелді айнымалы коэффициентті сызықтық комбинациясымен берілген шеттік есеп зерттелген. Келесі нәтижелер алынды: $0 \leq x \leq 2 \pi$ болғанда Трикоми есебінің деректерін тасымалдаушылар сияқты $\Omega$ облысында $\Omega_{1}$ бөлігін шектейтін $A C$ және $B C$ сипаттаушыларының тең мүмкіндікті еместігі көрсетілді және $B C$ сипаттаушыларындағы деректерімен Трикоми есебінің шешуінен, жалпы алғанда, $A C$ сипаттаушысындағы деректерімен Трикоми есебі шешілмейді; зерттеліп отырған есептің регулярлы шешуінің бар болуы және жалғыздығының қажетті және жеткілікті шарттары табылған. Берілген функцияға белгілі бір шарттарда зерттелетін есептің шешуі айқын түрде жазылды. Берілген функцияға жұмыста
\end{abstract}


табылған қажетті шарттар бұзылса, зерттелетін есепке сәйкес біртекті есептің шексіз көп шешуі болатыны көрсетілген, сәйкес біртекті емес есептің шешулер жиыны тек қана берілген функцияларға қосымша талаптар болғанда ғана бар болады.

Kiлm сөздер: аралас типті теңдеу, үшінші ретті парабола-гиперболалық теңдеу, Трикоми теңдеуі, ығысумен берілген бірінші теңдеу, Грин функциясы, екінші текті Фредгольмнің интегралдық теңдеуі.

Ж.А. Балкизов, З.Х. Гучаева, А.Х. Кодзоков

\title{
Первая задача со смещением для уравнения параболо-гиперболического типа третьего порядка и эффект неравноправия характеристик как носители данных задачи Трикоми
}

\begin{abstract}
В статье исследована краевая задача со смещением для неоднородного уравнения парабологиперболического типа третьего порядка с параболическим уравнением третьего порядка с обратным ходом времени и волновым уравнением в области гиперболичности, когда в качестве одного из граничных условий задана линейная комбинация с переменными коэффициентами от значений искомой функции на характеристиках $A C$ и $B C$. Получены следующие результаты: показано неравноправие характеристик $A C$ и $B C$, ограничивающих гиперболическую часть $\Omega_{1}$ области $\Omega$ как носители данных задачи Трикоми при $0 \leq x \leq 2 \pi$, и из разрешимости задачи Трикоми с данными на характеристике $B C$, вообще говоря, не следует разрешимость задачи Трикоми с данными на характеристике $A C$; найдены необходимые и достаточные условия существования и единственности регулярного решения исследуемой задачи. При определенных условиях на заданные функции решение исследуемой задачи выписано в явном виде. Показано, что при нарушении найденных в работе необходимых условий на заданные функции, однородная задача, соответствующая исследуемой задаче, имеет бесчисленное множество линейно независимых решений, а множество решений соответствующей неоднородной задачи может существовать только при дополнительном требовании на заданные функции.
\end{abstract}

Ключевые слова: уравнение смешанного типа, параболо-гиперболическое уравнение третьего порядка, задача Трикоми, метод Трикоми, первая задача со смещением, функция Грина, интегральное уравнение Фредгольма второго рода.

\section{References}

1 Dzhuraev, T.D. (1979). Kraevye zadachi dlia uravnenii smeshannoho i smeshanno-sostavnoho tipov [Boundary value problems for equations of mixed and mixed composite types]. Tashkent: FAN [in Russian].

2 Nahushev, A.M. (1995). Uravneniia matematicheskoi biolohii [The equations of mathematical biology]. Moscow: Vysshaia shkola [in Russian].

3 Nahushev, A.M. (2006). Zadachi so smeshcheniem dlia uravnenii v chastnykh proizvodnykh /Problems with displacement for partial differential equations]. Moscow: Nauka [in Russian].

4 Zhegalov, V.I. (1962). Kraevaia zadacha dlia uravneniia smeshannoho tipa s hranichnymi usloviiami na obeikh kharakteristikakh i s razryvami na linii perekhoda [The boundary value problem for a mixed type equation with boundary conditions on both characteristic lines and with gaps on the transition line]. Uchenye zapiski Kazanskoho universiteta, 122, 3, 3-16 [in Russian].

5 Nahushev, A.M. (1969). O nekotorykh kraevykh zadachakh dlia hiperbolicheskikh uravnenii i uravnenii smeshannoho tipa [On some boundary value problems for hyperbolic equations and equations of mixed type]. Differential equations, 5, 1, 44-59 [in Russian]. 
6 Nahushev, A.M. (1969). Novaia kraevaia zadacha dlia odnoho vyrozhdaiushchehosia hiperbolicheskoho uravneniia [A new boundary-value problem for one degenerate hyperbolic equation]. Doklady Akademii nauk SSSR - Doklady of the USSR Academy of Sciences, 187, 4, 736-739 [in Russian].

7 Nahushev, A.M. (1971). O zadache Darbu dlia vyrozhdaiushchikhsia hiperbolicheskikh uravnenii [On the Darboux problem for degenerate hyperbolic equations]. Differential equations, 7, 1, 49-56 [in Russian].

8 Bers, L. (1961). Matematicheskie voprosy dozvukovoi i okolozvukovoi hazovoi dinamiki /Mathematical problems of subsonic and transonic gas dynamics]. Moscow: Inostrannaia literatura [in Russian].

9 Frankl', F.I. (1973). Izbrannye trudy po hazovoi dinamike [Selected works on gas dynamics]. Moscow: Nauka [in Russian].

10 Salahitdinov, M.S. (1974). Uravneniia smeshanno-sostavnoho tipa /Equations of mixed-composite type]. Tashkent: FAN [in Russian].

11 Repin, O.A. (1992). Kraevye zadachi so smeshcheniem dlia uravnenii hiperbolicheskoho $i$ smeshannoho tipa [Boundary value problems with displacement for equations of hyperbolic and mixed type]. Samara: Izdatelstvo Samarskoho filiala Saratovskoho hosudarstvennoho universiteta [in Russian].

12 Kal'menov, T.Sh. (1993). Kraevye zadachi dlia lineinykh uravnenii v chastnykh proizvodnykh hiperbolicheskoho tipa [Boundary value problems for linear partial differential equations of hyperbolic type]. Shymkent: Hylaia [in Russian].

13 Zhegalov, V.I. \& Mironov, A.N. (2001). Differentsialnye uravneniia so starshimi chastnymi proizvodnymi [Differential equations with highest partial derivatives]. Kazan: Kazanskoe matematicheskoe obshchestvo [in Russian].

14 Repin, O.A., Kilbas, A.A. \& Marichev, O.I. (2008). Kraevye zadachi dlia uravnenii v chastnykh proizvodnykh s razryvnymi koeffitsientami [Boundary value problems for partial differential equations with discontinuous coefficients]. Samara: Iizdatelstvo Samarskoho hosudarstvennoho ekonomicheskoho universiteta [in Russian].

15 Pul'kina, L.S. (2012). Zadachi s neklassicheskimi usloviiami dlia hiperbolicheskikh uravnenii /Problems with nonclassical conditions for hyperbolic equations]. Samara: Izdatelstvo Samarskoho universiteta [in Russian].

16 Sabitov, K.B. (2014). K teorii uravnenii smeshannoho tipa /To the theory of equations of mixed type]. Moscow: Fizmatlit [in Russian].

17 Sabitov, K.B. (2015). Priamye i obratnye zadachi dlia uravnenii parabolo-hiperbolicheskoho tipa [Direct and inverse problems for equations of parabolic-hyperbolic type]. Ufa: Hilem [in Russian].

18 Nahusheva, Z.A. (2011). Nelokalnye kraevye zadachi dlia osnovnykh i smeshannoho tipov differentsialnykh uravnenii [Nonlocal boundary value problems for the basic and mixed types differential equations]. Nalchik: KBSC RAS [in Russian].

19 Salahitdinov, M.S. (1967). K teorii uravnenii treteho poriadka smeshanno-sostavnoho tipa [On the theory of third-order equations of mixed-composite type]. Doctor's thesis. Tashkent [in Russian]

20 Nahushev, A.M. (1970). K teorii lineinykh kraevykh zadach dlia hiperbolicheskikh i smeshannykh uravnenii vtoroho poriadka [On the theory of linear boundary value problems for hyperbolic and mixed second-order equations]. Doctor's thesis. Novosibirsk [in Russian].

21 Zhegalov, V.I. (1988). Issledovanie kraevykh zadach so smeshcheniem dlia uravnenii smeshannoho tipa [The study of boundary value problems with bias for equations of mixed type]. Doctor's thesis. Novosibirsk [in Russian]. 
22 Sabitov, K.B. (1991). Nekotorye voprosy kachestvennoi i spektralnoi teorii uravnenii smeshannoho tipa [On some questions of the qualitative and spectral theory of equations of mixed type]. Doctor's thesis. Moscow [in Russian].

23 Repin, O.A. (1998). Kraevye zadachi dlia uravnenii hiperbolicheskoho i smeshannoho tipov i drobnoe intehro-differentsirovanie [Boundary value problems for mixed hyperbolic types equations and fractional integro-differentiation]. Doctor's thesis. Minsk [in Russian].

24 Balkizov, Zh.A. (2019). Ob odnoi kraevoi zadache tipa zadachi Trikomi dlia uravneniia smeshannoho parabolo-hiperbolicheskoho tipa vtoroho poriadka s tremia smeshcheniiami v hiperbolicheskoi chasti oblasti [On a boundary value problem of Tricomi mixed type problem for an equation of the second order with three displacements in the hyperbolic part of the domain]. Nauchnye vedomosti Belhorodskoho hosudarstvennoho universiteta. Seriia Matematika. Fizika - Scientific reports of Belgorod State University. Mathematics Series. Physics, 51, 1, 5-14. DOI 10.18413/20754639-2019-51-1-5-14 [in Russian].

25 Repin, O.A. (1992). Nelokalnaia kraevaia zadacha dlia parabolo-hiperbolicheskoho uravneniia s kharakteristicheskoi liniei izmeneniia tipa [Nonlocal boundary value problem for a parabolichyperbolic equation with a characteristic line of type changing]. Differential equations, 28, 1, 173-176 [in Russian]

26 Kilbas, A.A. \& Repin, O.A. (1998). Zadacha so smeshcheniem dlia parabolo-hiperbolicheskoho uravneniia [Problem with displacement for a parabolic-hyperbolic equation]. Differential equations, 34, 6, 799-805 [in Russian].

27 Repin, O.A. \& Efimova, S.V. (2002). Nelokalnaia kraevaia zadacha dlia parabolo-hiperbolicheskoho uravneniia $\mathrm{s}$ nekharakteristicheskoi liniei izmeneniia tipa [Nonlocal boundary value problem for a parabolic-hyperbolic equation with an uncharacteristic line of type changing]. Vestnik Samarskoho hosudarstvennoho universiteta. Seriia fiziko-matematicheskikh nauk - Bulletin of Samara State Technical University. Series Phys.-Math. Science, 16, 10-14 [in Russian].

28 Efimova, C.V. \& Repin, O.A. (2004). Zadacha s nelokalnymi usloviiami na kharakteristikakh dlia uravneniia vlahoperenosa [A problem with nonlocal conditions with characteristics for a moisture transfer equation]. Differential equations, 40:10, 1498-1502 [in Russian].

29 Mirsaburov, M. \& Chorieva, S.T. (2016). O zadache s tremia variantami smeshchenii dlia uravneniia smeshannoho tipa [On a problem with three variants of displacements for a mixed type equation]. Izvestiia vuzov. Seriia Matematika - News of Universities. Maths, 2016, 4, 32-45 [in Russian].

30 Efimova, S.V. (2005). Nelokalnaia zadacha dlia hiperbolicheskoho uravneniia, vyrozhdaiushchehosia vnutri oblasti [Nonlocal problem for a hyperbolic equation degenerating inside a domain]. Bulletin of Samara State Technical University. Series Phys.-Math. science, 34, 194-196 [in Russian].

31 Balkizov, Zh.A. (2018). Kraevaia zadacha so smeshcheniem dlia modelnoho uravneniia parabolohiperbolicheskoho tipa treteho poriadka [A boundary value problem with an displacement for a model equation of parabolic-hyperbolic type of the third order]. Vestnik KRAUNTS. Phiz.-mat. sciences, 3(23), 19-26 [in Russian].

32 Tihonov, A.N. \& Samarskii, A.A. (1977). Uravneniia matematicheskoi fiziki [Equations of mathematical physics]. Moscow: Nauka, 736 [in Russian]. 